\title{
ANALISIS KESULITAN BELAJAR MATEMATIKA MATERI OPERASI HITUNG CAMPURAN SISWA MI HIJRIYAH II PALEMBANG
}

\author{
Emi Zakiah Oktari ${ }^{1}$, Tutut Handayani ${ }^{2}$, Fuaddilah Ali Sofyan ${ }^{3}$ \\ 1,2,3 Prodi Pendidikan Guru Madrasah Ibtidaiyah \\ Universitas Islam Negeri Raden Fatah Palembang \\ J1. Prof. K.H.Zainal Abidin Fikri, Palembang, Sumatera Selatan, Indonesia \\ E-mail : emizakiyah26@gmail.com ${ }^{1}$, tututhandayani_uin@ radenfatah.ac.id ${ }^{2}$, \\ fuadpgmi_uin@radenfatah.ac.id ${ }^{3}$
}

Website: https://jurnal.uin-antasari.ac.id/index.php/adzka

Received: Juni 2019; Accepted: Juni 2019; Published: Juni 2019

\begin{abstract}
The purpose of this research is to find out the forms, factors that caused, the effort to overcome of difficulty learning mathematics in calculating mixed operating material for $\mathrm{IV}^{\mathrm{D}}$ graders at MI Hijriyah II Palembang. This type of research is qualitative descriptive. Informants of this study were Madrasah heads, math teachers and $\mathrm{IV}^{\mathrm{D}}$ graders who had learning difficulties. Data collection techniques are observation, interview and documentation. Data analysis techniques are data reduction, data presentation and conclusion drawing. The results of this study are (1) The forms of difficulty learning mathematics material of mixed counting operations, namely students have difficulty calculating while doing the exercises, understanding symbols, understanding concepts and writing the sum of. (2) The factors that cause difficulties in learning mathematics in mixed counting operating materials, namely internal factors such as concentration of learning does not last long, the ability to remember some students is low, difficult to understanding the purpose of the problem and difficulty counting. External factors such as teachers in providing understanding too quickly, do not use media and students who often speak when the teacher explains. (3) Efforts to overcome learning difficulties, namely holding tutoring, holding remedials for low grades, changing methods used, giving motivation and advice, using media that is appropriate to the material.
\end{abstract}

Keywords: difficulty learning; mathematics; mixed counting operating material.

\begin{abstract}
ABSTRAK
Tujuan penelitian ini untuk mengetahui bentuk-bentuk; faktor yang menyebabkan dan upaya mengatasi kesulitan belajar matematika materi operasi hitung campuran siswa kelas IV ${ }^{\mathrm{D}}$ di MI Hijriyah II Palembang. Jenis penelitian ini deskriptif kualitatif. Informan penelitian ini yaitu kepala Madrasah, guru matematika dan siswa kelas $\mathrm{IV}^{\mathrm{D}}$ yang mengalami kesulitan belajar. Teknik pengumpulan data yaitu observasi, wawancara dan dokumentasi. Teknik analisis data yaitu reduksi data, penyajian data dan penarikan kesimpulan. Hasil penelitian menyebutkan (1) bentuk kesulitan belajar matematika materi operasi hitung campuran yaitu siswa sulit menghitung saat mengerjakan latihan, memahami simbol; memahami konsep dan menuliskan hasil penjumlahan bilangan. (2) faktor yang menyebabkan kesulitan belajar matematika materi operasi hitung campuran yaitu faktor internal seperti konsentrasi belajar tidak bertahan lama, kemampuan mengingat beberapa siswa rendah, siswa berkesulitan dalam memahami maksud soal dan kesulitan menghitung. Faktor eksternalnya seperti guru dalam memberikan pemahaman terlalu cepat, tidak menggunakan media dan siswa yang sering berbicara pada saat guru menjelaskan. (3) upaya untuk mengatasi kesulitan belajar yaitu diadakannya bimbingan belajar, mengadakan remedial untuk yang nilainya rendah, mengubah metode yang digunakan, memberi motivasi dan nasehat, menggunakan media yang sesuai materi.
\end{abstract}

Kata Kunci: kesulitan belajar; matematika; materi operasi hitung campuran. 


\section{PENDAHULUAN}

Pendidikan merupakan aktivitas yang akan selalu terjadi dan menjadi kebutuhan setiap manusia. Pendidikan sebagai proses untuk menyiapkan generasai muda dalam memenuhi tujuan kehidupannya dan membuat masa depan menjadi yang lebih baik. Oleh sebab itu pendidikan sangat penting di dalam kehidupan manusia dan merupakan hak setiap manusia untuk mendapatkannya.

Definisi pendidikan di Indonesia yang tercantum dalam Undang-Undang tentang Sistem Pendidikan Nasional No. 20 Tahun 2003, Bab 1 Pasal 1 Ayat 1 mengemukakan "Pendidikan adalah usaha sadar dan terencana untuk mewujudkan suasana belajar dan proses pembelajaran agar peserta didik secara aktif mengembangkan potensi dirinya untuk memiliki kekuatan spiritual keagamaan, pengendalian diri, kepribadian, kecerdasan, akhlak mulia, serta keterampilan yang diperlukan dirinya, masyarakat, bangsa dan negara" (Rusmaini, 2014: 1-2). Dengan demikian, dapat disimpulkan bahwa pendidikan merupakan suatu proses untuk menyiapkan generasi muda agar dapat menjalankan kehidupannya dan memenuhi tujuan hidupnya secara lebih baik.

Proses pelaksanaannya pendidikan berfungsi sebagai alat untuk mencapai tujuan pendidikan, yakni kompetensi yang harus dicapai dalam ikhtiar pendidikan. Bagaimanapun bagus dan idealnya suatu rumusan kompetensi, pada akhirnya keberhasilan sangat tergantung kepada pelaksanaan proses pembelajaran yang dilakukan guru. Pembelajaran yang ideal adalah pembelajaran yang melibatkan siswa secara aktif dan menekankan bagaimana cara agar tujuan dapat tercapai. Menurut Warsita (Rusman, 2017: 85) pembelajaran adalah suatu usaha untuk membuat siswa belajar atau suatu kegiatan untuk membelajarkan siswa. Dengan kata lain pembelajaran merupakan upaya untuk menciptakan kondisi agar terjadi kegiatan belajar.

Belajar merupakan suatu usaha yang dilakukan oleh individu dalam interaksi untuk memperoleh perubahan tingkah laku dari yang tidak mengerti menjadi mengerti agar mendapatkan suatu ilmu. Menuntut ilmu sangatlah penting bagi setiap manusia, hal ini disebebkan ilmu akan mengangkat derajat manusia dalam kehidupan yang lebih baik. Allah berfirman dalam surat Al-Mujadilah ayat 11:

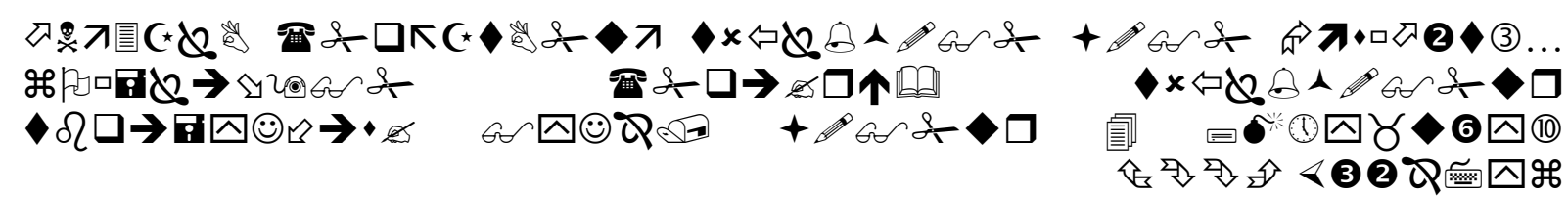

Artinya: “...niscaya Allah akan meninggikan orang-orang yang beriman di antaramu dan orang-orang yang diberi ilmu pengetahuan beberapa derajat. dan Allah Maha mengetahui apa yang kamu kerjakan".

Ayat ini menyatakan bahwa antara iman, ilmu dan amal merupakan sistematik dalam struktur kehidupan setiap muslim yang akan mengantarkan mereka pada tingkat derajat yang tinggi. Maka dari setiap manusia harus belajar dengan giat untuk mendapatkan ilmu pengetahuan karena Allah mengetahui apa yang dilakukan oleh setiap umatnya.

Matematika merupakan salah satu bidang studi yang ada pada semua jenjang pendidikan mulai dari tingkat sekolah dasar hingga perguruan tinggi. Bahkan matematika diajarkan di taman kanak-kanak secara informal. Ada beberapa banyak alasan tentang perlunya siswa belajar matematika. Cornelius mengemukakan lima alasan perlunya belajar matematika karena matematika merupakan sarana berpikir yang jelas dan logis, sarana untuk memecahkan masalah kehidupan sehari-hari, sarana mengenal pola-pola hubungan dan generalisasi pengalaman, sarana untuk meningkatkan kreativitas dan sarana untuk meningkatkan kesadaran terhadap perkembangan budaya (Mulyono Abdurrahman, 2012: 204). 
Secara umum, tujuan pembelajaran matematika di sekolah dasar adalah agar siswa mampu dan terampil menggunakan matematika. Selain itu juga, dengan pembelajaran matematika dapat memberikan tekanan penataran nalar dalam penerapan matematika. Menurut Depdiknas, kompetensi atau kemampuan umum pembelajaran matematika di sekolah dasar yaitu melakukan operasi hitung penjumlahan, pengurangan, perkalian, pembagian, beserta operasi campurannya, termasuk yang melibatkan pecahan; menentukan sifat dan unsur berbagai bangun datar dan bangun ruang sederhana, tremasuk penggunaan sudut, keliling, luas dan volume; menentukan sifat simetri, kesebangunan, dan sistem koordinat; menggunakan pengukuran yaitu satuan, kesetaraan antarsatuan, dan penaksiran pengukuran; menentukan dan menafsirkan data sederhana seperti ukuran tertinggi, terendah, rata-rata, modus, mengumpulkan dan menyajikannya; memecahkan masalah, melakukan penalaran, dan mengomunikasikan gagasan secara matematika (Ahmad Susanto, 2013: 189-190)

Meskipun matematika memiliki kegunaan dan peranan yang penting dalam kehidupan sehari-hari. Menurut peneliti banyak siswa yang beranggapan bahwa matematika merupakan salah satu mata pelajaran yang sulit untuk dipelajari dan dipahami. Pemikiran siswa yang mengganggap matematika sulit itulah yang kemudian membuat siswa mengalami kesulitan dalam mempelajari matematika. Hal ini sering terlihat pada siswa yang cenderung bersifat pasif dan mendapatkan nilai rendah di sekolah. Selain itu kesulitan dari memahami materi matematika apabila mendapat tugas dari gurunya tidak dapat dilaksanakannya dengan baik dan hal ini menyebabkan hasil belajarnya menjadi menurun.

Hal tersebut juga dibenarkan oleh siswa yang telah diwawancara pada tanggal 25 Februari 2019 bahwa pada saat pembelajaran matematika siswa lebih banyak diam dan tidak memperhatikan pada saat guru menjelaskan materi di depan kelas. Pada saat mengerjakan latihan yang diberikan guru siswa tersebut tidak dapat mengerjakan latihan dengan baik karena kurang memahami dan mengerti materi yang sudah dijelaskan guru sehingga mendapatkan nilai yang rendah.

Menurut Blassic dan Jones (Muhamad Irham dan Novan Ardy, 2017: 254), kesulitan belajar yang dialami siswa menunjukkan adanya kesenjangan atau jarak antara prestasi akademik yang diharapkan dengan prestasi akademik yang dicapai oleh siswa pada kenyataannya (prestasi aktual). Siswa akan dikatakan mengalami kesulitan belajar apabila intelegensi yang dimilikinya tergolong rata-rata atau normal. Akan tetapi, menunjukkan adanya kekurangan dalam proses dan hasil belajar seperti prestasi belajar yang diperolehnya rendah. Oleh sebab itu, kesulitan belajar merupakan suatu kondisi saat siswa mengalami hambatanhambatan tertentu untuk mengikuti proses pembelajaran dan mencapai hasil belajar secara optimal. Dengan demikian, adanya kesulitan belajar dan hambatan belajar yang dialami siswa akan berdampak atau dapat dilihat pada prestasi belajar yang dicapai oleh siswa yang bersangkutan.

Kesulitan belajar matematika yang dihadapi siswa ditandai dalam beberapa kekeliruan umum dalam mengerjakan soal matematika, yaitu kekeliruan dalam memahami simbol, nilai tempat, perhitungan, penggunaan proses yang keliru, dan tulisan yang tidak dapat dibaca (Mulyono Abdurrahman, 2012: 213). Oleh karena itu, untuk meningkatkan pemahaman siswa terhadap matematika, perlu diwujudkan pembelajaran matematika yang menyenangkan dalam berbagai materi.

Berdasarkan hasil observasi yang dilakukan di MI Hijriyah II Palembang pada tanggal 18 April 2019 telah didapatkan informasi bahwa terdapat beberapa siswa yang mengalami kesulitan belajar pada mata pelajaran matematika dan beberapa siswa mendapatkan nilai yang rendah pada materi operasi hitung campuran. Dari nilai rendah yang didapatkan oleh siswa maka harus diketahui penyebab dari kesulitan yang dialami oleh siswa dalam proses belajar matematika. 
Dari latar belakang permasalahan diatas, maka penulis bermaksud melakukan penelitian dengan judul "Analisis Kesulitan Belajar Matematika Materi Operasi Hitung Campuran Siswa Kelas IV Di MI Hijriyah II Palembang”. Tujuan dalam penelitian ini antara lain: (1) untuk mengetahui bentuk-bentuk kesulitan belajar matematika materi operasi hitung campuran siswa kelas IVD di MI Hijriyah II Palembang, (2) untuk mengetahui faktor-faktor yang menyebabkan kesulitan belajar matematika materi operasi hitung campuran siswa kelas IV $^{\mathrm{D}}$ di MI Hijriyah II Palembang, (3) untuk menjelaskan upaya mengatasi kesulitan belajar matematika materi operasi hitung campuran siswa kelas IVD di MI Hijriyah II Palembang.

\section{METODO PENELITIAN}

Jenis penelitian ini adalah deksriptif kualitatif. Sumber data premier berupa data yang diperoleh dari kepala Madrasah, guru mata pelajaran matematika kelas IV $^{\mathrm{D}}$ dan siswa berkenaan dengan kesulitan belajar matematika yang didapat melalui wawancara dan observasi. Sedangkan sumber data sekunder meliputi dokumen-dokumen, arsip-arsip yang berhubungan dengan penelitian ini diperoleh melalui dokumentasi.

Adapun yang menjadi informan di dalam penelitian ini adalah siswa kelas $\mathrm{IV}^{\mathrm{D}}$ yang mengalami kesulitan belajar, kepala Madrasah dan guru mata pelajaran matematika kelas IV ${ }^{\mathrm{D}}$ MI Hijriyah II Palembang. Teknik pengambilan sampel pada penelitian kualitatif adalah purposive sampling adalah teknik pengambilan sumber data dengan pertimbangan tertentu. Pengambilan sampel ini bisa berdasarkan seleksi khusus. Peneliti membuat kriteria tertentu siapa yang dijadikan sebagai informan (Helen Sabera Adib, 2016: 44).

Teknik pengumpulan data dalam penelitian ini menggunakan observasi partisipasi pasif, wawancara semi terstruktur yang pelaksanaannya lebih bebas dan lebih terbuka serta dokumentasi berbentuk tulisan, gambar atau sejarah kehiduoan dan biografi. Dokumentasi ini merupakan pelengkap dari hasil observasi dan wawancara. Analisis data dalam penelitian kualitatif menggunakan analisis data Miles dan Huberman. Untuk melakukan analisis data diperlukan beberapa proses (Andi Prastowo, 2016: 240-250) yaitu reduksi data (Data Reduction), penyajian data (data display) dan penarikan kesimpulan (conclusion drawing/verification).

Data yang diperoleh dari penelitian ini harus diuji keabsahannya, agar data dapat diterima dan dipertanggungjawabkan. Adapun bentuk-bentuk uji keabsahan data (Andi Prastowo, 2016: 266-275) yaitu uji kredibilitas data, uji dependabilitas data, uji transferabilitas dan uji konfirmabilitas.

\section{HASIL DAN PEMBAHASAN}

\section{A. Hasil Penelitian}

\section{Bentuk Kesulitan Belajar Matematika Materi Operasi Hitung Campuran}

Kesulitan belajar adalah suatu keadaan dimana siswa sulit untuk belajar atau menerima dan memahami pelajaran sebagaimana mestinya. Kesulitan belajar tersebut menggambarkan adanya hambatan dalam proses belajar mengajar, dalam kondisi seperti ini siswa tidak dapat mencapai hasil belajar yang baik atau prestasinya menurun. Berdasarkan hasil wawancara yang dilakukan peneliti kepada wakil kepala Madrasah, guru dan siswa-siswi kelas IVD mengenai bentuk-bentuk kesulitan belajar matematika materi operasi hitung campuran yaitu guru kurang menggunakan media dalam pembelajaran, siswa sulit menghitung pada saat mengerjakan latihan yang diberikan guru, kesulitan dalam memahami simbol dan memahami konsep yaitu siswa sering lupa tanda negatif (-) berarti hutang dan dalam menuliskan hasil penjumlahan bilangan yang seharusnya negatif dibuat positif. 
Tabel 1. Hasil Latihan Matematika Materi Operasi Hitung Campuran Siswa Kelas IV ${ }^{D}$ MI Hijriyah II Palembang

\begin{tabular}{|c|c|c|c|}
\hline No. & Nilai & Jumlah & Persentase \\
\hline 1. & 0 & 0 & 0,00 \\
\hline 2. & 25 & 1 & 2,78 \\
\hline 3. & 50 & 18 & 50,00 \\
\hline 4. & 75 & 12 & 33,33 \\
\hline 5. & 100 & 5 & 13,89 \\
\hline \multicolumn{2}{|c|}{$\mathbf{6 4 , 5 8}$} \\
\hline
\end{tabular}

Berdasarkan hasil observasi kesulitan belajar matematika materi operasi hitung campuran, peneliti melihat pada saat siswa mengerjakan soal yang diberikan guru, ada siswa yang konsentrasi, teliti dan tidak mengalami kesulitan saat mengerjakan latihan dan ada siswa yang tidak konsentrasi dan berbicara pada teman di sebelah saat mengerjakan latihan sehingga pada saat harus mengumpulkan latihan, siswa tersebut tidak dapat menyelesaikan latihan yang diberikan. Peneliti melihat dari keseluruhan siswa yang berjumlah 36 orang terhadap dokumen latihan, nilai yang dimiliki atau yang didapat oleh 17 orang siswa saat mengerjakan tugas yang diberikan oleh guru mendapatkan nilai sesuai KKM dan 19 orang siswa mendapatkan nilai yang tidak sesuai KKM atau mendapat nilai yang sangat kecil.

\section{Faktor yang Menyebabkan Kesulitan Belajar Matematika Materi Operasi Hitung Campuran}

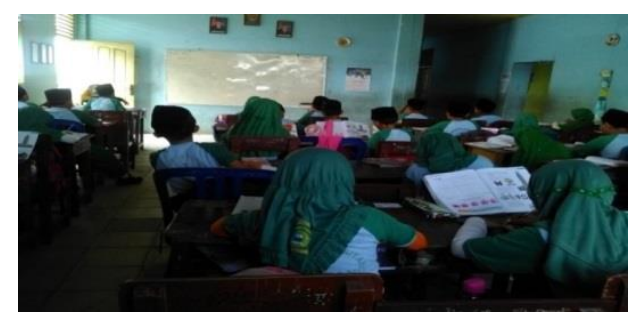

Gambar 1. Keadaan Siswa saat Mengerjakan Latihan

Berdasarkan hasil observasi yang dilakukan peneliti pada tanggal 18 April 2019, guru mengajarkan materi operasi hitung campuran tentang penjumlahan dan pengurangan bilangan positif dan negatif hanya menggunakan buku pelajaran. Untuk media daftar perkalian, guru tersebut menggunakannya pada materi yang berhubungan dengan perkalian. Selain itu siswa binggung dalam menghitung bilangan negatif dan positif yang dijumlahkan dan dikurangkan serta saat mengerjakan latihan yang diberikan guru karena pada saat guru menjelaskan ada siswa yang tidak konsentrasi walaupun situasi kelas sudah kondusif, selain itu juga karena terbatasnya waktu yang hanya 35 menit sehingga pada saat latihan sering mendapatkan nilai yang tidak sesuai dengan KKM atau nilai rendah.

Berdasarkan hasil wawancara yang dilakukan peneliti kepada wakil kepala Madrasah, guru dan siswa-siswi kelas IVD mengenai faktor-faktor yang menyebabkan kesulitan belajar matematika materi operasi hitung campuran yaitu faktor internal dan faktor eksternal. Faktor internal yang mempengaruhi kesulitan belajar matematika siswa adalah tidak aktifnya siswa dalam pembelajaran, konsentrasi belajar tidak bertahan lama, kemampuan mengingat beberapa siswa rendah, siswa berkesulitan dalam memahami maksud soal dan kesulitan menghitung. Faktor eksternal yang mempengaruhi kesulitan belajar siswa adalah guru dalam memberikan pemahaman terlalu cepat, tidak menggunakan media dalam pembelajaran, beberapa siswa yang tidak nyaman di kelas dan siswa yang sering berbicara pada saat guru menjelaskan. 
Emi Zakiah Oktari, dkk

\section{Upaya Mengatasi Kesulitan Belajar Matematika Materi Operasi Hitung Campuran}

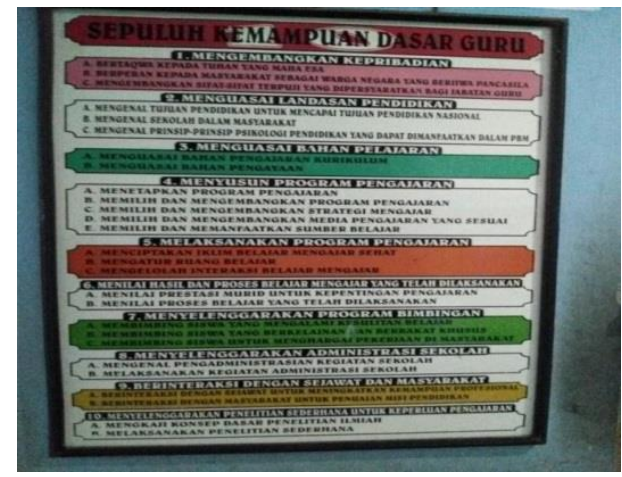

Gambar 2. Sepuluh Kemampuan Dasar Guru

Adapun observasi yang dilakukan peneliti pada tanggal 16 April 2019 bahwa di MI Hijriyah II Palembang terdapat papan sepuluh kemampuan guru yang terdapat pada nomor 7 yaitu menyelenggarakan program bimbingan belajar untuk membimbing siswa yang mengalami kesulitan belajar, membimbing siswa yang berkelainan/berbakat khusus dan memebimbing siswa untuk menghargai pekerjaan di masyarakat.

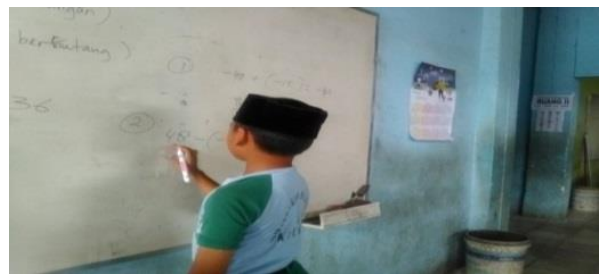

\section{Gambar 3. Siswa Mengerjakan Soal di Papan Tulis}

Berdasarkan hasil observasi pada tanggal 18 April 2019, mengenai kesulitan belajar matematika materi operasi hitung campuran peneliti melihat bahwa upaya yang dilakukan untuk mengatasi kesulitan belajar tersebut yaitu dengan memberikan motivasi, nasehat kepada siswa saat pembelajaran. Guru juga meminta siswa untuk mengerjakan soal di papan tulis untuk mengetahui apakah siswa tersebut mengerti dan menguasi materi yang diajarkan.

Berdasarkan hasil wawancara yang dilakukan peneliti mengenai upaya mengatasi kesulitan belajar matematika materi operasi hitung campuran yaitu dengan diadakannya bimbingan belajar atau pelajaran tambahan di luar jam sekolah, mengadakan remedial untuk siswa yang mendapat nilai rendah, mengubah metode yang digunakan, memberikan motivasi dan nasehat, menggunakan media yang sesuai dengan materi, serta harus mengenalkan, mengingatkan, memberikan pemahaman tentang simbol bilangan agar anak tidak keliru dalam menghitung dan menyelesaikan soal.

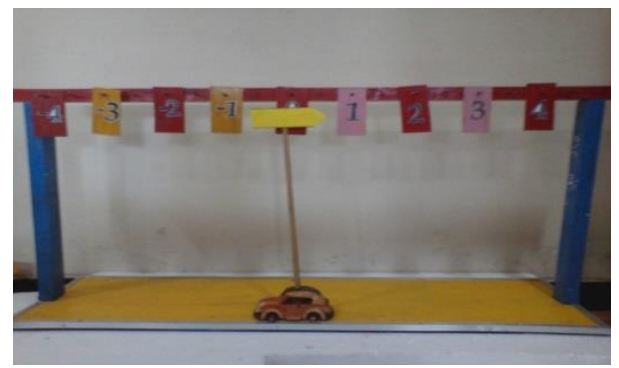

Gambar 4. Media Garis Bilangan 


\section{B. Pembahasan}

\section{Bentuk Kesulitan Belajar Matematika Materi Operasi Hitung Campuran}

Beberapa kesulitan umum tersebut menurut Lerner dalam Mulyono Abdurrahman yaitu kekurangan pemahaman tentang simbol; nilai tempat; penggunaan proses yang keliru; perhitungan; tulisan yang tidak dapat dibaca. (Mulyono Abdurrahman, 2012: 214-215). Jadi kesulitan belajar matematika itu merupakan suatu kondisi proses belajar yang ditandai hambatan-hambatan tertentu untuk mencapai hasil belajar. Aktivitas belajar bagi setiap individu tidak selamanya dapat berlangsung secara wajar. Kadang-kadang lancar, kadang-kadang tidak, kadang-kadang dapat cepat menangkap apa yang dipelajari, kadang-kadang terasa sangat sulit. Dalam hal semangat terkadang semangatnya tinggi tetapi terkadang juga sulit untuk mengadakan konsentrasi.

Berdasarkan hasil penelitian yang dilakukan peneliti mengenai bentuk-bentuk kesulitan belajar matematika materi operasi hitung campuran yaitu guru kurang menggunakan media dalam pembelajaran, siswa sulit menghitung pada saat mengerjakan latihan yang diberikan guru, kesulitan dalam memahami simbol dan memahami konsep yaitu siswa sering lupa tanda negatif (-) berarti hutang dan dalam menuliskan hasil penjumlahan bilangan yang seharusnya negatif dibuat positif. Misalnya 6 dibaca 9 sehingga ditambahkan dengan 2 hasilnya 11. Jadi dari kesulitan umum menurut Lerner dalam Mulyono Abdurrahman yang sama dengan penelitian yang dilakukan yaitu kekurangan pemahaman simbol, penggunaan proses yang keliru, dan perhitungan.

\section{Faktor yang Menyebabkan Kesulitan Belajar Matematika Materi Operasi Hitung Campuran}

Banyak hal yang dapat menghambat dan mengganggu kemajuan belajar bahkan sering juga terjadi suatu kegagalan tetapi pada pokoknya dapat digolongkan menjadi dua faktor yaitu faktor internal dan eksternal. Faktor internal merupakan faktor yang dating dari diri siswa sendiri seperti faktor biologi (kesehatan dan cacat badan) serta psikologis (intelegensi, perhatian, minat bakat, dan emosi). Sedangkan faktor eksternal merupakan faktor yang dating dari luar siswa seperti lingkungan keluarga, sekolah, dan masyarakat (Zainal Aqib, 2010: 62$67)$.

Menurut Djamarah (2008: 237-242), secara garis besar faktor-faktor penyebab timbulnya kesulitan belajar yaitu faktor siswa, sekolah, dan keluarga. faktor siswa meliputi intelegensi yang kurang baik; bakat yang kurang atau tidak sesuai dengan bahan pelajaran yang dipelajari atau yang diberikan oleh guru; kesehatan yang kurang baik misalnya sakit kepala, sakit perut, sakit mata, dan sakit gigi; serta tidak ada motivasi dalam belajar. Faktor sekolah meliputi media/alat yang kurang memadai; guru tidak memiliki kecakapan dalam usaha mendiagnosis kesulitan belajar siswa; suasana sekolah yang kurang menyenangkan; perpustakaan sekolah yang kurang memadai dan kurang merangsang penggunaannya oleh siswa. Faktor keluarga meliputi kurang kelengkapan alat-alat belajar bagi anak di rumah; anak tidak mempunyai ruang dan tempat belajar yang khusus di rumah; perhatian orang tua yang tidak memadai.

Berdasarkan hasil penelitian yang dilakukan peneliti mengenai faktor-faktor yang menyebabkan kesulitan belajar matematika materi operasi hitung campuran yaitu Faktor internal yang mempengaruhi kesulitan belajar matematika siswa adalah tidak aktifnya siswa dalam pembelajaran, siswa yang kurang konsentrasi, kemampuan mengingat beberapa siswa rendah, siswa berkesulitan dalam memahami maksud soal dan kesulitan menghitung. Faktor eksternal yang mempengaruhi kesulitan belajar siswa adalah guru dalam memberikan pemahaman terlalu cepat, tidak menggunakan media dalam pembelajaran, beberapa siswa yang tidak nyaman di kelas dan siswa yang sering berbicara pada saat guru menjelaskan. Jadi faktorfaktor yang menyebabkan kesulitan belajar dalam Zainal Aqib yang sama dengan penelitian 
yang dilakukan yaitu faktor internal seperti faktor psikologis (faktor bersifat rohaniah) seperti intelegensi, perhatian, dan minat. Sedangkan faktor yang menyebabkan kesulitan belajar dalam Syaiful Bahri Jamarah yaitu intelegensi yang kurang baik, dan tidak ada motivasi dalam belajar. sementara faktor eksternal yang menyebabkan kesulitan belajar dalam Zainal Aqib yaitu dari lingkungan sekolah seperti cara penyajian pelajaran kurang baik dan alat-alat di sekolah yang serba tidak lengkap. Sedangkan faktor eksternal yang menyebabkan kesulitan belajar dalam Syaiful Bahri Jamarah yaitu alat/media yang kurang memadai, suasana sekolah yang kurang menyenangkan.

\section{Upaya Mengatasi Kesulitan Belajar Matematika Materi Operasi Hitung Campuran}

Siswa yang mengalami kesulitan belajar terutama dalam mata pelajaran matematika harus dibantu dan dibimbing oleh guru yang bersangkutan. Adapun upaya mengatasi kesulitan belajar matematika materi operasi hitung campuran yaitu guru harus menggunakan media pembelajaran yang menarik untuk membuat siswa merasa bersemangat dan tertarik dalam pembelajaran serta untuk menunjang pembelajaran agar siswa dapat memahami materi dengan baik; sebelum pelajaran dilanjutkan upayakan mengulang pelajaran terlebih dahulu karena hubungan pelajaran yang akan dilanjutkan atau pelajaran tersebut saling keterkaitan. Bila siswa kurang berhasil belajar sendiri dapat dicarikan teman kelompok belajar dan peranan orangtua sangat dibutuhkan dalam membimbing anak yang kurang berhasil dalam belajar sendiri; dan guru harus membuat proses pembelajaran menyenangkan agar siswa tersebut bersemangat dalam pembelajaran (Lisnawaty Simanjutak, Dkk, 1993: 48)

Dari hasil peneltian yang dilakukan bahwa upaya untuk mengatasi kesulitan belajar matematika materi operasi hitung campuran yaitu dengan diadakannya bimbingan belajar atau pelajaran tambahan di luar jam sekolah, mengadakan remedial untuk siswa yang mendapat nilai rendah, mengubah metode yang digunakan, memberikan motivasi dan nasehat, menggunakan media yang sesuai dengan materi, serta harus mengenalkan, mengingatkan, memberikan pemahaman tentang simbol bilangan agar anak tidak keliru dalam menghitung dan menyelesaikan soal.

Jadi upaya yang dilakukan untuk mengatasi kesulitan belajar dalam Lisnawaty Simanjuntak yang sama dengan hasil penelitian yang dilakukan yaitu guru harus menggunakan media pembelajaran yang menarik untuk membuat siswa merasa bersemangat dan tertarik dalam pembelajaran serta untuk menunjang pembelajaran agar siswa dapat memahami materi dengan baik dan guru harus membuat proses pembelajaran menyenangkan agar siswa tersebut bersemangat dalam pembelajaran.

\section{PENUTUP}

Bentuk-bentuk kesulitan belajar matematika materi operasi hitung campuran yaitu guru kurang menggunakan media dalam pembelajaran, siswa sulit menghitung pada saat mengerjakan latihan yang diberikan guru, kesulitan dalam memahami simbol dan memahami konsep yaitu siswa sering lupa tanda negatif (-) berarti hutang dan dalam menuliskan hasil penjumlahan bilangan yang seharusnya negatif dibuat positif. Faktor internal yang mempengaruhi kesulitan belajar matematika siswa adalah tidak aktifnya siswa dalam pembelajaran, konsentrasi belajar tidak bertahan lama, kemampuan mengingat beberapa siswa rendah, siswa berkesulitan dalam memahami maksud soal dan kesulitan menghitung. Faktor eksternal yang mempengaruhi kesulitan belajar siswa adalah guru dalam memberikan pemahaman terlalu cepat, tidak menggunakan media dalam pembelajaran, siswa yang sering berbicara pada saat guru menjelaskan.

Upaya yang dilakukan untuk mengatasi kesulitan belajar di MI Hijriyah II Palembang yaitu diadakannya bimbingan belajar atau pelajaran tambahan di luar jam sekolah, mengadakan remedial untuk siswa yang mendapat nilai rendah, mengubah metode yang digunakan, 
memberikan motivasai dan nasehat, menggunakan media yang sesuai dengan materi, serta harus mengenalkan, mengingatkan, memberikan pemahaman tentang simbol bilangan agar anak tidak keliru dalam menghitung dan menyelesaikan soal.

\section{DAFTAR PUSTAKA}

Adib, Helen Sabera. 2016. Metodologi Penelitian. Palembang: Noerfikri Offset.

Aqib, Zainal. 2010. Profesionalisme Guru Dalam Pembelajaran. Surabaya: Insan Cendekia.

Abdurrahman, Mulyono. 2012. Anak Berkesulitan Belajar: Teori, Diagnosis, Dan Remediasinya. Jakarta : Rineka Cipta.

Djamarah, Syaiful Bahri. 2008. Psikologi Belajar. Jakarta: Rineka Cipta.

Muhamad Irham dan Novan Ardy Wiyani. 2017. Psikologi Pendidikan: Teori Dan Aplikasi Dalam Proses Pembelajaran. Yogyakarta: Ar-Ruzz Media.

Rusman. 2017. Belajar Dan Pembelajaran Berorientasi Standar Proses Pendidikan. Jakarta: Kencana.

Rusmaini. 2014. Ilmu Pendidikan. Palembang: Grafika Telindo Press.

Prastowo, Andi. 2016. Metode Penelitian Kualitatif Dalam Perspektif Rancangan Penelitian. Yogyakarta: Ar-Ruzz Media.

Simanjutak, Lisnawaty Dkk. 1993. Metode Mengajar Matematika 1. Jakarta; Rineka Cipta

Susanto, Ahmad. 2013. Teori Belajar Dan Pembelajaran Di Sekolah Dasar. Jakarta: Prenadamedia Group. 
Emi Zakiah Oktari, dkk 